\title{
PERBANDINGAN KEPADATAN MARSHALL DAN KEPADATAN MUTLAK (PRD) PADA CAMPURAN BERASPAL
}

\author{
Ranna Kurnia \\ Staf pengajar Jurusan Teknik Sipil Itenas Bandung \\ Jl. PKH Hasan Mustapa No. 2340124 Bandung. \\ Email: kurniaranna@gmail.com
}

\begin{abstract}
ABSTRAK
Umumnya campuran beraspal dirancang menggunakan metoda Marshall konvensional di laboratorium dengan pemadatan benda uji sebanyak 2 x 75 tumbukan untuk lalu lintas berat dan batas rongga campuran antara 3\% - 5\%. Hasil pengendalian mutu menunjukkan bahwa parameter kontrol dilapangan seringkali tidak terpenuhi sehingga metoda Marshall konvensional belum cukup menjamin kinerja campuran beraspal sesuai spesifikasi. Perancangan campuran beraspal dengan metoda kepadatan mutlak (PRD) dilakukan dengan batasan rongga campuran maksimum 3\% dengan pemadat getar listrik (vibratory hammer) atau menggunakan pemadat Marshall. Tujuan penelitian ini adalah mengkaji dan membandingkan parameter kepadatan campuran beraspal antara tiga metoda pemadatan yaitu Marshall 2x75 tumbukan, Marshall 2x400 tumbukan, dan vibratory hammer. Berdasarkan hasil penelitian diketahui pada kadar aspal yang tinggi, kurva kepadatan ketiga metoda cenderung berimpit. Hal ini mengindikasikan bahwa campuran Marshall konvensional 2x75 tumbukan dapat mendekati kondisi membal (kepadatan maksimum) tanpa harus menambah jumlah tumbukan jika menggunakan kadar aspal yang tinggi.
\end{abstract}

Kata kunci : Kepadatan campuran beraspal, pemadat Marshall, vibratory hammer

\section{Pendahuluan}

Pemadatan adalah proses dimana partikelpartikel solid dirapatkan secara mekanis sehingga volume rongga dalam campuran mengecil dan kepadatan campuran meningkat. Selain itu, pemadatan juga mengatur distribusi partikel agregat dalam campuran sehingga menghasilkan konfigurasi agregat optimum dalam mencapai kepadatan yang ditargetkan.

Perancangan campuran beraspal di Indonesia umumnya menggunakan metoda Marshall konvensional dengan pemadatan benda uji sebanyak 2x75 tumbukan untuk lalu lintas berat dan batas rongga campuran antara 3\%-5\%. Hasil pengendalian mutu menunjukkan bahwa parameter kontrol dilapangan seringkali tidak terpenuhi sehingga metoda Marshall konvensional belum cukup menjamin kinerja campuran beraspal sesuai spesifikasi. Salah satu faktor utama keterbatasan metoda Marshall adalah ketergantungan terhadap kepadatan setelah dilalui kendaraan untuk mencapai rongga udara yang disyaratkan. Rongga dalam campuran setelah dilalui lalu lintas dalam beberapa tahun mencapai $<1 \%$ sehingga terjadi perubahan bentuk plastis. Berdasarkan hal tersebut, saat ini digunakan perancangan campuran beraspal dengan metoda kepadatan mutlak (PRD) yang bertujuan untuk menjamin tidak adanya perubahan bentuk plastis (plastic deformation) setelah pemadatan oleh lalu lintas. Dengan kondisi ini, diharapkan kinerja perkerasan jalan aspal akan meningkat.

\section{Studi Pustaka}

Kepadatan campuran beraspal (mix density) adalah berat campuran yang diukur tiap satuan volume. Kepadatan merupakan tingkat kerapatan campuran setelah campuran dipadatkan. Kepadatan campuran beraspal akan meningkat seiring dengan meningkatnya kadar aspal hingga mencapai nilai maksimum, setelah itu nilainya akan turun.

Berdasarkan pedoman Ditjen Bina Marga (1999), kepadatan mutlak dimaksudkan sebagai 
kepadatan tertinggi (maksimum) yang dicapai sehingga campuran tersebut praktis tidak dapat menjadi lebih padat lagi. Kepadatan mutlak merupakan pendekatan terhadap kondisi lapangan setelah campuran beraspal dipadatkan secara sekunder oleh lalu lintas selama beberapa tahun umur rencana.

Pemadatan campuran beraspal di laboratorium umumnya menggunakan pemadat Marshall sebanyak 2x75 tumbukan untuk setiap benda uji berdiameter 4 inci. Jika benda uji yang digunakan berdiameter 6 inci maka pemadatan dilakukan sebanyak 2x600 tumbukan. Akan tetapi di dalam Spesifikasi Umum (2010) Bina Marga disarankan menggunakan pemadat getar listrik (vibratory hammer) agar pecahnya butiran agregat dalam campuran dapat dihindari.

Pemadatan campuran beraspal menggunakan pemadat getar listrik mengacu pada British Standard 598-104-2005 dengan menggunakan alat-alat seperti ditunjukkan pada gambar 1 . Frekuensi dan waktu pembebanan sangat mempengaruhi hasil pemadatan. Frekuensi yang digunakan yaitu antara $20 \mathrm{~Hz}-50 \mathrm{~Hz}$. Waktu pembebanan antara 2 detik - 10 detik untuk masing-masing posisi seperti pada gambar 3 . Total waktu pembebanan tidak boleh melebihi $120 \pm 5$ detik. Total berat pemadat sesuai standar adalah $10 \mathrm{~kg}$. Benda uji menggunakan cetakan mold 6-inci.
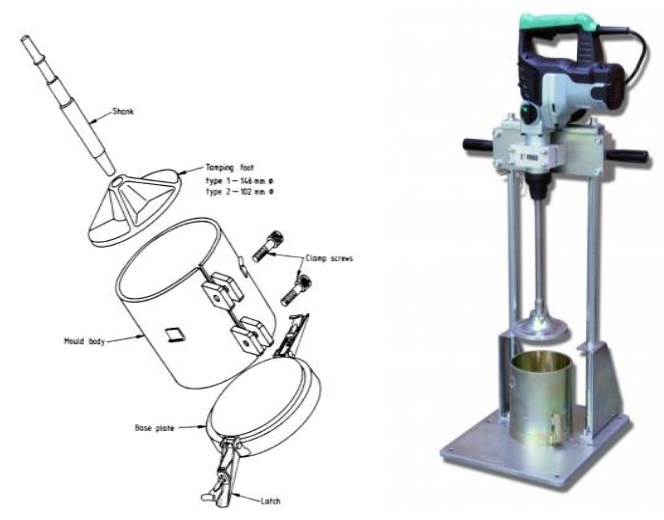

Gambar 1. Alat Pemadat Getar Listrik

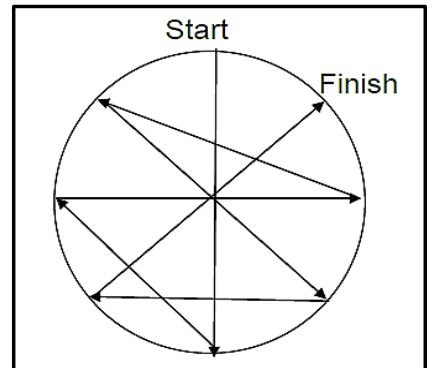

Gambar 2. Alur Pemadatan Campuran (British Standard, 2005)

Perbandingan kepadatan campuran beraspal pernah dilakukan oleh Dachlan (1997) dengan membandingkan kepadatan mutlak hasil tes laboratorium dengan kepadatan lapangan hasil core drill pada jalur Pantai Utara (Pantura) Jawa Barat seperti ditunjukkan pada tabel 1 . Kepadatan mutlak hasil tes laboratorium ratarata lebih besar 2\% dibandingkan kepadatan hasil core drill. Dachlan juga menyebutkan proses pemadatan dengan pemadat getar listrik lebih cepat daripada pemadatan Marshall. Selain itu, pengaruh pemadatan vibrasi terhadap agregat dan temperatur lebih kecil dibandingkan pemadatan Marshall.

Penelitian yang lain (Shuler, et.al., 1992) juga menyebutkan bahwa pemadatan dengan pemadat getar listrik menghasilkan kepadatan yang lebih tinggi dibandingkan pemadat Marshall konvensional lainnya tanpa menimbulkan degradasi agregat yang terlihat dari volume rongga campuran yang lebih kecil, seperti ditunjukkan pada gambar 3 .

PUERI PERBANDINGAN KEPADATAN MARSHALL DAN KEPADATAN MUTLAK (PRD) PADA CAMPURAN BERASPAL 
Tabel 1. Perbandingan Kepadatan Mutlak Hasil Laboratorium dan Kepadatan Hasil Core Drill (Dachlan, 1997)

\begin{tabular}{cccc}
\hline & In situ & & \\
& Density & Laboratory Refusal \\
Location & (Core & Densities \\
& Drill & & \\
& Samples $)$ & & \\
& $(\mathrm{Mg} / \mathrm{m} 3)$ & & \\
& & Vibratorry & Extended \\
West & & Hammer & Marshall Test \\
Java & & & $(400$ blows $)$ \\
(Northern & Mean $=$ & Mean $=$ & Mean $=2.418$ \\
Corridor $)$ & 2.376 & 2.421 & \\
& & & \\
& Std $=$ & Std $=$ & Std $=0.020$ \\
& 0.037 & 0.025 & \\
\hline
\end{tabular}

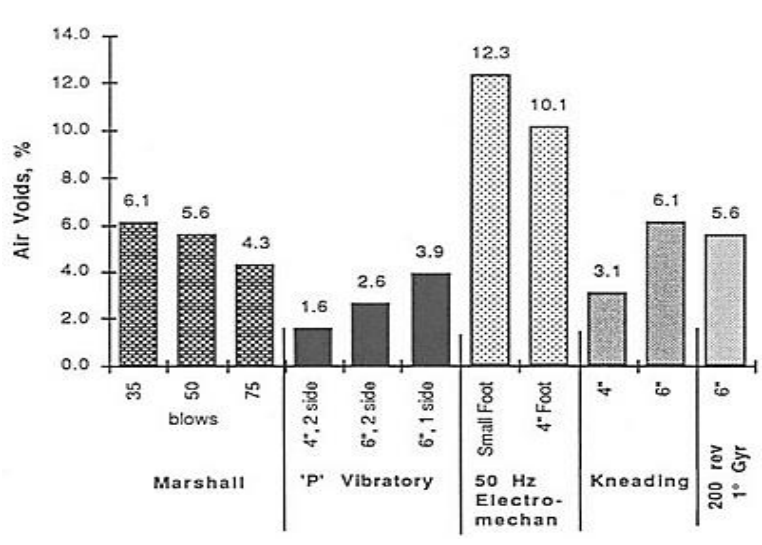

Gambar 3. Perbandingan Volume Rongga Udara Berbagai Metoda Pemadatan (Shuler, et.al., 1992)

\section{Metodologi}

Penelitian dan pengambilan data dilakukan di laboratorium Rekayasa Jalan dan Lalu Lintas ITB. Sebelum pencampuran dan pemadatan benda uji, terlebih dahulu dilakukan pengujian karakteristik bahan aspal dan agregat. Bahan yang dipakai harus memenuhi persyaratan dalam Spesifikasi Umum (2010). Dalam penelitian ini digunakan aspal pen 40/50 Pertamina dan agregat dari Kabupaten Karawang. Aspal pen 40/50 dipilih karena berdasarkan Asphalt Institute MS-2 (1995), jenis aspal yang cocok untuk wilayah tropis seperti Indonesia adalah aspal yang memiliki nilai pen rendah. Berikut ini bagan alir yang menujukkan tahapan-tahapan penelitian.

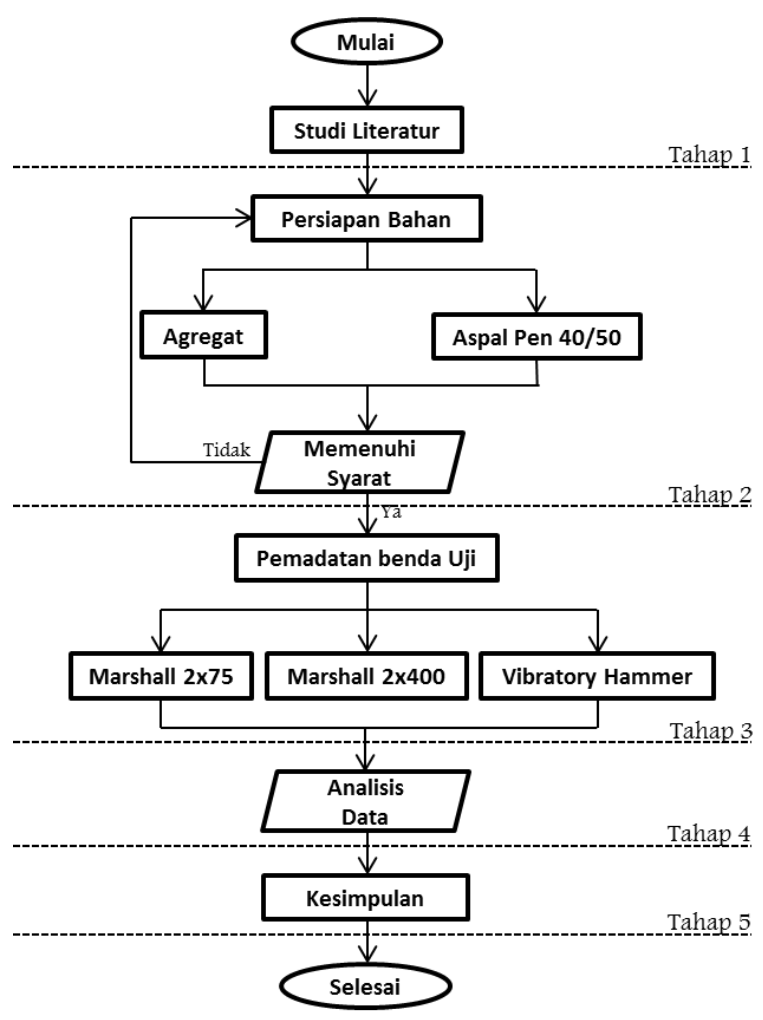

Gambar 4. Bagan Alir Penelitian

Pada tahap 1 dilakukan kajian terhadap literatur dan hasil pengujian campuran beraspal laboratorium sebelumnya. Kajian dilakukan untuk menentukan gradasi campuran, jenis aspal, jenis pengujian, metoda pemadatan dan karakteristik campuran berdasarkan hasil pengujian. Jenis gradasi campuran yang dipilih dalam penelitian ini adalah Asphalt Institute (Asphalt Institute MS-2, 1995) dengan ukuran nominal maksimum agregat $19 \mathrm{~mm}$. Gradasi ini dipilih karena relatif dekat dan sejajar kurva Fuller. Menurut Sukirman (2003), kurva Fuller adalah kurva gradasi agregat dimana kondisi campuran memiliki kepadatan maksimum dengan rongga diantara mineral agregat (VMA) minimum. Kurva gradasi campuran Asphalt Institute dan kurva Fuller ditunjukkan pada gambar 5 berikut ini.

PUEnI PERBANDINGAN KEPADATAN MARSHALL DAN KEPADATAN MUTLAK (PRD) PADA CAMPURAN BERASPAL 


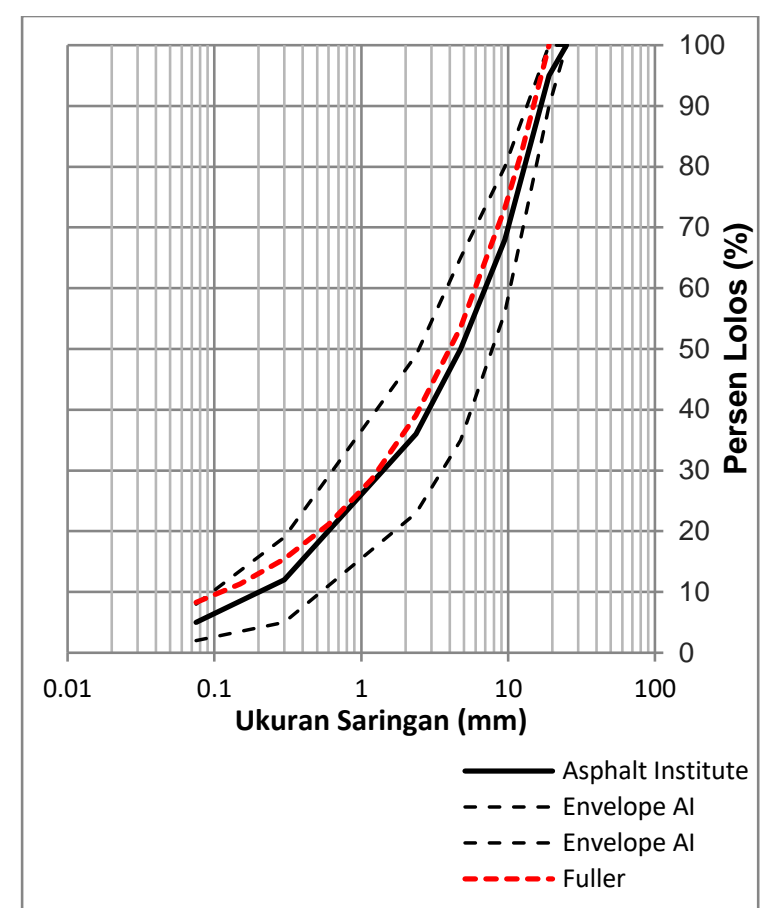

Gambar 5. Kurva Gradasi Asphalt Institute NMAS $19 \mathrm{~mm}$ (Asphalt Institute MS-2, 1995)

Tahap berikutnya adalah penyiapan dan pengujian bahan seperti pada tahap 2. Pengujian bahan dilakukan untuk mengetahui kualitas bahan. Jika bahan tersebut tidak memenuhi persyaratan dalam spesifikasi maka pengujian diulang. Setiap pengujian bahan dilakukan secara duplo. Khusus pada bahan aspal, pengujian rheologi dilakukan untuk mengetahui sifat-sifat rheologi dari aspal.

Jika tahap 2 pengujian bahan sudah memenuhi persyaratan maka tahap selanjutnya pada tahap 3 adalah pembuatan benda uji dengan pemadatan Marshall konvensional 2x75 tumbukan, Marshall 2x400 tumbukan, dan vibratory hammer. Diameter benda uji Marshall yang digunakan adalah 4 inci, sedangkan diameter benda uji vibratory hammer adalah 6 inci. Pada rentang kadar aspal 5\%-7\% umumnya diperoleh kurva kepadatan yang tidak memiliki nilai puncak (maksimum) sehingga dalam penelitian ini benda uji juga dilakukan pada kadar aspal 8\%, walaupun resiko terjadi bleeding sangat besar. Jumlah benda uji yang dibuat 18 sampel seperti pada tabel 2 .
Tabel 2. Jumlah Benda Uji

\begin{tabular}{|c|c|c|c|}
\hline $\begin{array}{c}\text { Kadar } \\
\text { Aspal }\end{array}$ & $\begin{array}{c}\text { Marshall } \\
2 \times 75 \\
\text { Tumbukan }\end{array}$ & $\begin{array}{c}\text { Marshall } \\
2 \times 400 \\
\text { Tumbukan }\end{array}$ & $\begin{array}{c}\text { Vibrator } \\
y \\
\text { Hammer }\end{array}$ \\
\hline $5,0 \%$ & 1 & 1 & 1 \\
\hline $5,5 \%$ & 1 & 1 & 1 \\
\hline $6,0 \%$ & 1 & 1 & 1 \\
\hline $6,5 \%$ & 1 & 1 & 1 \\
\hline $7,0 \%$ & 1 & 1 & 1 \\
\hline $8,0 \%$ & 1 & 1 & 1 \\
\hline $\begin{array}{c}\text { Total } \\
\text { Benda Uji }\end{array}$ & & 18 & \\
\hline
\end{tabular}

Analisis data yang dilakukan pada tahap 4 adalah analisis kepadatan campuran beraspal. Seperti yang telah dijelaskan sebelumnya, kepadatan sangat mempengaruhi karakteristik campuran beraspal. Pada benda uji tersebut tidak dilakukan pengujian stabilitas Marshall dan hanya dilakukan uji volumetrik campuran. Dari perbandingan kurva kepadatan dapat diketahui metoda pemadatan yang menghasilkan kepadatan maksimum. Selain itu, perbandingan kepadatan Marshall konvensional 2x75 tumbukan terhadap kepadatan mutlak baik Marshall 2x400 dan vibratory hammer dapat diketahui.

Berdasarkan hasil analisis kepadatan campuran beraspal dari ketiga metoda pemadatan kemudian disimpulkan sebagai hasil penelitian pada tahap 5 .

\section{IV.Hasil dan Analisis}

Berdasarkan hasil pengujian di laboratorium diperoleh karakteristik bahan agregat dan aspal memenuhi persyaratan dalam spesifikasi. Pedoman pengujian agregat dan aspal yang digunakan mengacu pada AASHTO (2008) Standard Spesifications for Transportation Materials and Methods and Testing. Hasil pengujian karakteristik bahan aspal dan agregat

PUERI PERBANDINGAN KEPADATAN MARSHALL DAN KEPADATAN MUTLAK (PRD) PADA CAMPURAN BERASPAL

Ranna Kurnia 
ditunjukkan pada tabel 3 dan tabel 4. Pengujian DSR (Dynamic Shear Rheometer) dalam penelitian ini juga dilakukan untuk mengetahui sifat rheologi aspal pen 40/50. Selain itu, nilai PG (Performance Grade) juga dapat diketahui dari hasil pengujian DSR.

Tabel 3.Hasil Pengujian Karakteristik Agregat

\begin{tabular}{|c|c|c|c|c|}
\hline \multirow{2}{*}{ Jenis Pemeriksaan } & \multicolumn{2}{|c|}{ Spesifikasi } & \multirow{2}{*}{$\begin{array}{l}\text { Hasil Uji } \\
\text { (1) }\end{array}$} & \multirow{2}{*}{$\begin{array}{c}\text { Hasil } \\
\text { Uji } \\
(2)\end{array}$} \\
\hline & Min. & Maks. & & \\
\hline Abrasi, $(\%)$ & - & 40 & 21.89 & 21.15 \\
\hline Soundness, (\%) & - & 12 & 5.70 & 4.12 \\
\hline$A I V,(\%)$ & - & 30 & 5.23 & 5.27 \\
\hline$A C V,(\%)$ & - & 30 & 14.51 & 14.54 \\
\hline Kepipihan, (\%) & - & 25 & 4.00 & 2.00 \\
\hline Kelonjongan, (\%) & - & 10 & 5.00 & 2.00 \\
\hline Kelekatan Agregat, (\%) & 95 & - & 95.00 & 98.00 \\
\hline Lolos No.200, (\%) & - & 1 & 0.876 & 0.820 \\
\hline
\end{tabular}

\begin{tabular}{|c|c|c|c|c|}
\hline Jenis Pemeriksaan & $\begin{array}{l}\text { Spes } \\
\text { Min. }\end{array}$ & $\begin{array}{l}\text { fikasi } \\
\text { Maks } \\
\text {. }\end{array}$ & $\begin{array}{l}\text { Hasil } \\
\text { Uji (1) }\end{array}$ & $\begin{array}{l}\text { Hasil } \\
\text { Uji } \\
(2)\end{array}$ \\
\hline Penetrasi, dmm & 40 & 50 & 45.40 & 46.00 \\
\hline Viskositas, cSt & 325 & - & 500.83 & 498.6 \\
\hline Titik lembek, ${ }^{\circ} \mathrm{C}$ & 51 & 63 & 51 & 51.25 \\
\hline Indeks Penetrasi & - & - & & \\
\hline Daktilitas, cm & 100 & - & $>100$ & $>100$ \\
\hline Titik Nyala, ${ }^{\circ} \mathrm{C}$ & 230 & - & 342 & 346 \\
\hline Titik Bakar, ${ }^{\circ} \mathrm{C}$ & 230 & - & 351 & 358 \\
\hline Kelarutan Aspal, \% & 99 & - & 99.99 & 99.95 \\
\hline Berat Jenis, $\mathrm{kg} / \mathrm{m} 3$ & 1 & - & 1.039 & 1.040 \\
\hline $\begin{array}{l}\text { Kehilangan } \quad \text { Berat } \\
\text { TFOT, \% }\end{array}$ & - & 0.8 & 0.296 & - \\
\hline $\begin{array}{l}\text { Penetrasi setelah } \\
\text { TFOT, \% asli }\end{array}$ & 55 & - & 82.71 & - \\
\hline $\begin{array}{l}\text { Titik Lembek setelah } \\
\text { TFOT, }{ }^{\circ} \mathrm{C}\end{array}$ & - & - & 54.50 & 55.00 \\
\hline $\begin{array}{l}\text { Daktilitas setelah } \\
\text { TFOT, cm }\end{array}$ & - & - & $>100$ & $>100$ \\
\hline $\begin{array}{l}\text { Kehilangan berat } \\
\text { RTFOT, } \%\end{array}$ & - & - & 0.023 & 0.014 \\
\hline $\begin{array}{l}\text { DSR } \\
\text { Binder, },{ }^{\circ} \mathrm{C}\end{array}$ & - & - & 68.72 & 68.66 \\
\hline $\begin{array}{l}\text { DSR }, \text { Setelah } \\
\text { RTFOT, }{ }^{\circ} \mathrm{C}\end{array}$ & - & - & 68.28 & 68.20 \\
\hline $\begin{array}{l}\text { DSR } \\
\text { PAV },{ }^{\circ} \mathrm{C}\end{array}$ & - & - & 23.23 & 23.67 \\
\hline $\begin{array}{l}\text { Pressure Aging } \\
\text { Vessel (PAV), } \%\end{array}$ & - & - & 0.313 & 0.404 \\
\hline
\end{tabular}

Data pengujian viskositas dengan alat Saybolt Furol pada temperatur pada temperatur $120 \mathrm{oC}$, $140 \mathrm{oC}$, dan $160 \mathrm{oC}$ kemudian diplot dalam

Tabel 4. Hasil Pengujian Karakteristik Aspal Pen 40/50 
grafik semi-log hubungan antara viskositas dan temperatur. Dari grafik ini kemudian ditentukan temperatur pencampuran dan pemadatan untuk kebutuhan pembuatan campuran beraspal. Temperatur pencampuran adalah temperatur pada viskositas $170 \pm 20$ Cst, sedangkan temperatur pemadatan pada $280 \pm 30$ Cst. Dari grafik diperoleh temperatur pencampuran dan pemadatan aspal pen 40/50 yaitu $154,5 \mathrm{oC}$ dan $145 \mathrm{oC}$ seperti ditunjukkan pada gambar 6 .

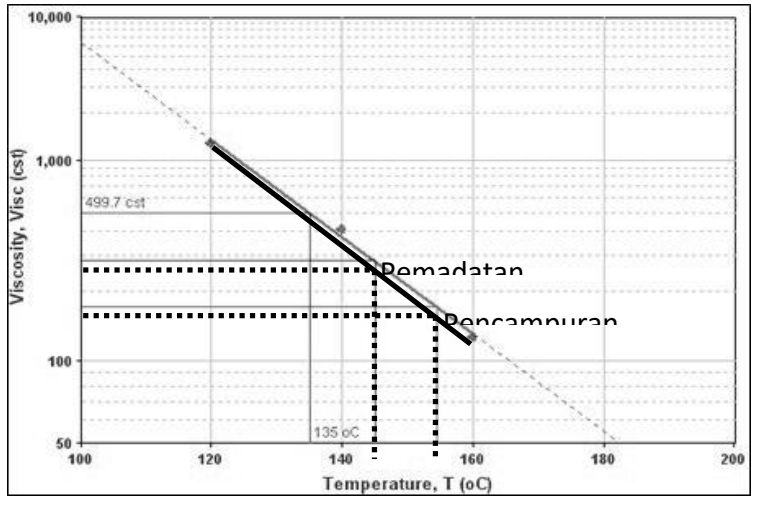

Gambar 6. Temperatur Pencampuran dan Pemadatan

Hasil pemadatan benda uji campuran Asphalt Institute dengan penumbuk Marshall 2x75 dan $2 \times 400$ menghasilkan kepadatan campuran seperti pada tabel 5 dan tabel 6 . Hasil pemadatan benda uji dengan vibratory hammer ditunjukkan tabel 7. Kepadatan maksimum Marshall 2x75 diperoleh oleh benda uji pada kadar aspal $7 \%$ sedangkan kepadatan maksimum Marshall 2x400 dan vibratory hammer diperoleh pada kadar aspal $6,5 \%$ dan $7 \%$ seperti ditunjukkan pada gambar 7, gambar 8 dan gambar 9 .

Tabel 5. Hasil Kepadatan Metoda Marshall $2 \times 75$

\begin{tabular}{c|cccc}
\hline $\begin{array}{c}\text { Kadar } \\
\text { aspal }(\%)\end{array}$ & $\begin{array}{c}\text { Kepadatan } \\
(\mathrm{t} / \mathrm{m} 3)\end{array}$ & $\begin{array}{c}\text { VIM } \\
(\%)\end{array}$ & $\begin{array}{c}\text { VMA } \\
(\%)\end{array}$ & $\begin{array}{c}\text { VFB } \\
(\%)\end{array}$ \\
\hline 5.0 & 2.300 & 8.80 & 18.25 & 51.68 \\
5.5 & 2.334 & 7.01 & 17.48 & 61.09 \\
6.0 & 2.361 & 5.30 & 17.09 & 68.95 \\
6.5 & 2.377 & 3.91 & 16.88 & 76.30 \\
7.0 & 2.386 & 2.78 & 16.82 & 83.20 \\
\hline
\end{tabular}

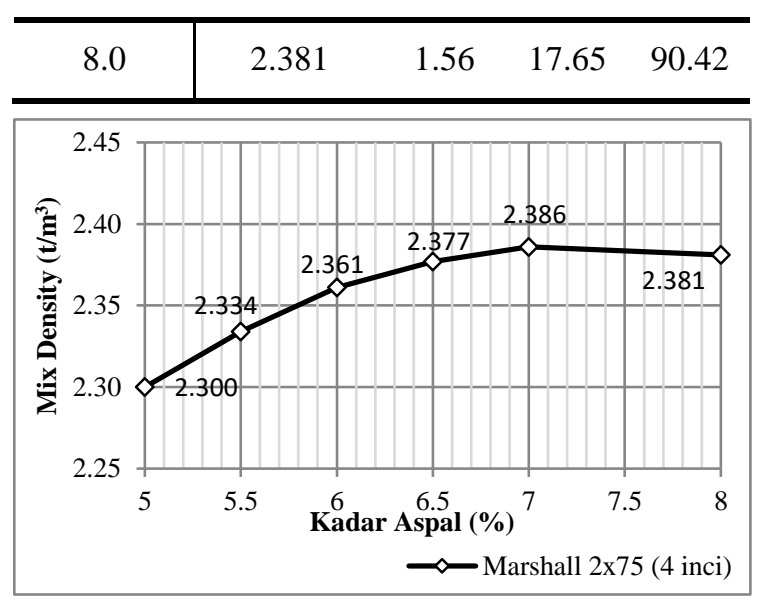

Gambar 7. Kepadatan Campuran Metoda Marshall $2 \times 75$

Tabel 6. Hasil Kepadatan Metoda Marshall $2 \times 400$

\begin{tabular}{c|cccc}
\hline $\begin{array}{c}\text { Kadar } \\
\text { Aspal }(\%)\end{array}$ & $\begin{array}{c}\text { Kepadatan } \\
(\mathrm{t} / \mathrm{m} 3)\end{array}$ & $\begin{array}{c}\text { VIM } \\
(\%)\end{array}$ & $\begin{array}{c}\text { VMA } \\
(\%)\end{array}$ & $\begin{array}{c}\text { VFB } \\
(\%)\end{array}$ \\
\hline 5.0 & 2.363 & 6.10 & 16.01 & 61.73 \\
5.5 & 2.381 & 4.80 & 15.59 & 70.23 \\
6.0 & 2.398 & 3.72 & 15.62 & 77.48 \\
6.5 & 2.403 & 2.82 & 15.87 & 81.68 \\
7.0 & 2.400 & 2.20 & 16.36 & 85.22 \\
8.0 & 2.384 & 1.31 & 17.50 & 90.10 \\
\hline
\end{tabular}

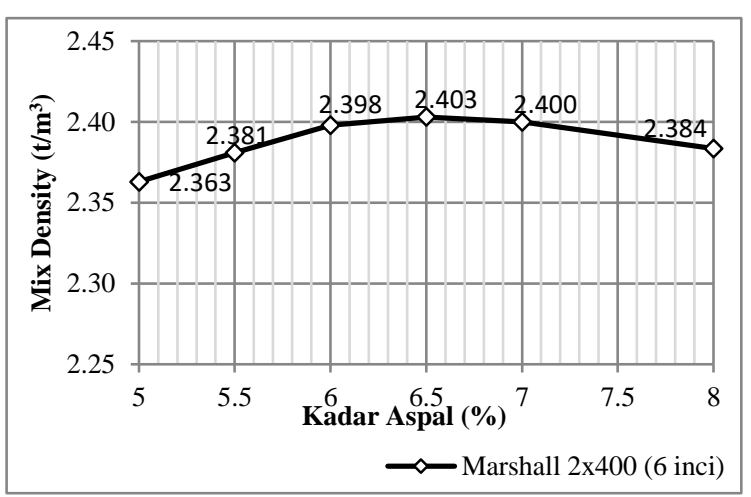

Gambar 8. Kepadatan Campuran Metoda Marshall $2 \times 400$ PUEERI PERBANDINGAN KEPADATAN MARSHALL DAN KEPADATAN MUTLAK (PRD) PADA CAMPURAN
BERASPAL

Ranna Kurnia 
Tabel 7. Hasil Kepadatan Benda Uji Vibratory Hammer

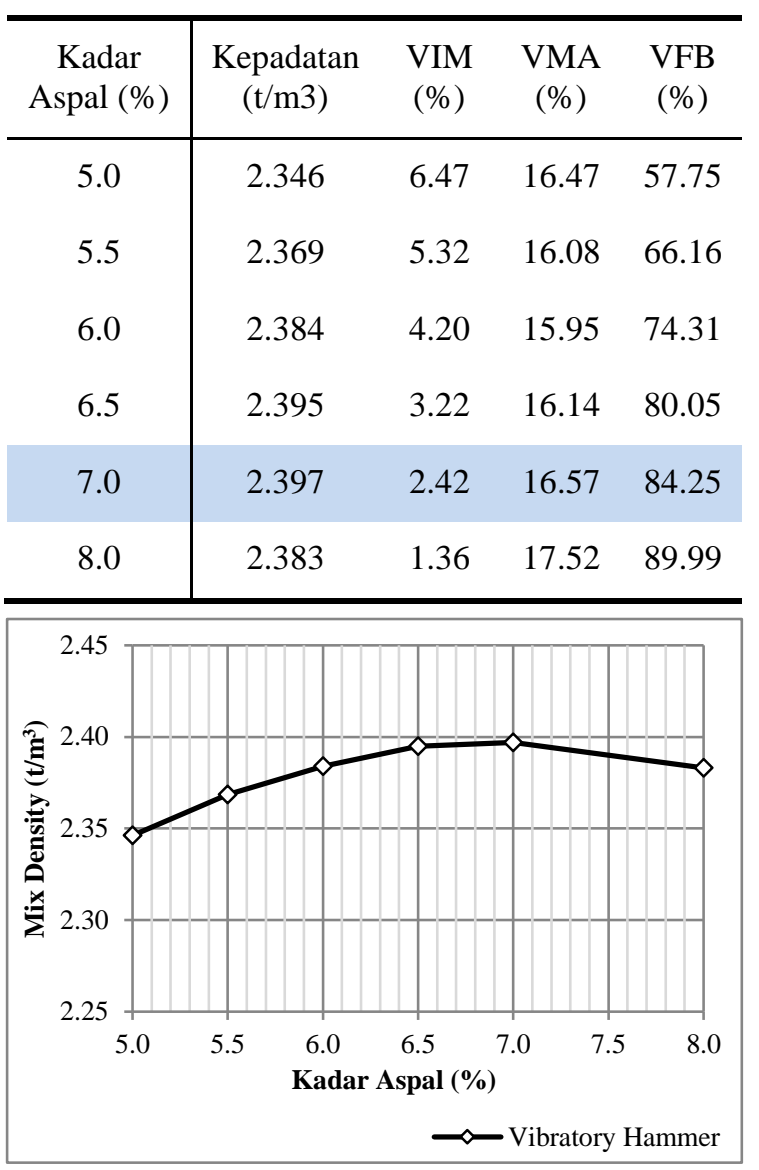

Gambar 9. Kepadatan Campuran Metoda Vibratory Hammer

Jika ketiga kurva kepadatan digabungkan maka diperoleh kurva kepadatan tertinggi ditunjukkan oleh pemadatan Marshall 2x400 tumbukan seperti gambar 10. Hasil ini berbeda dengan beberapa penelitian terdahulu dimana kepadatan dengan penggetar listrik lebih tinggi dibandingkan dengan penumbuk Marshall konvensional. Akan tetapi, perlu dilakukan penelitian lebih lanjut pengaruh pemadatan pada benda uji Marshall 6 inci.

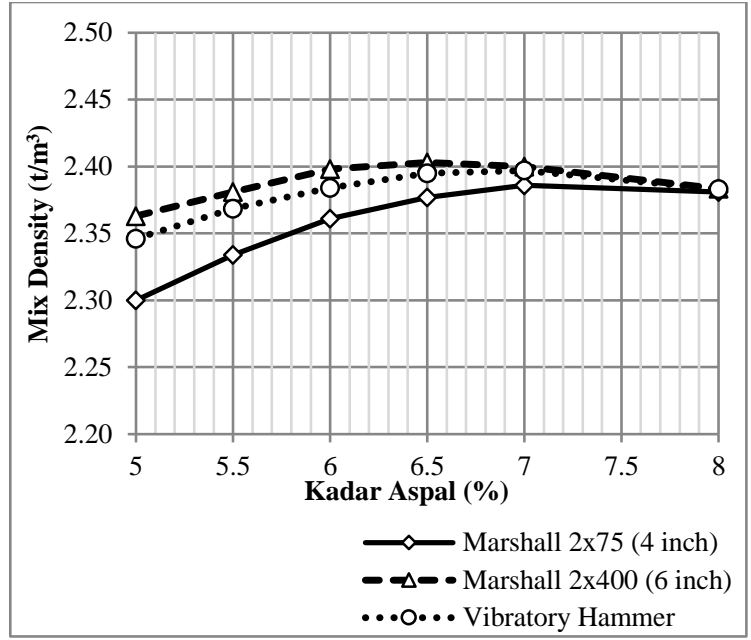

Gambar 10. Perbandingan Kepadatan Campuran Ketiga Metoda Pemadatan

Dari gambar 9 juga diketahui bahwa pada kadar aspal tinggi 5\%-6.5\%, campuran Marshall 2x75 masih dapat dipadatkan hingga mencapai kepadatan maksimum karena masih tersedia rongga. Oleh karena itu, perancangan campuran beraspal dengan pendekatan kepadatan mutlak (PRD) lebih baik daripada metoda Marshall konvensional.

Hal lainnya yang dapat terlihat adalah pada kadar aspal tinggi 7\%-8\%, kurva kepadatan cenderung berimpit. Hal ini mengindikasikan bahwa campuran Marshall konvensional 2x75 dapat mendekati kondisi membal (kepadatan maksimum) tanpa harus menambah jumlah tumbukan jika menggunakan kadar aspal yang lebih tinggi. Dengan jumlah aspal yang cukup maka rongga dalam campuran akan berkurang.

\section{V.Kesimpulan}

Dari hasil analisis data hasil pengujian di laboratorium, maka dapat diambil beberapa kesimpulan sebagai berikut:

Perancangan campuran beraspal dengan pendekatan kepadatan mutlak (PRD) menghasilkan kepadatan yang lebih tinggi daripada perancangan dengan metoda Marshall konvensional $2 \times 75$ tumbukan.

Dibandingkan dengan pemadatan vibrasi dengan alat penggetar listrik (vibratory 
hammer), pemadatan dengan penumbuk Marshall 2x400 tumbukan menghasilkan kepadatan campuran yang lebih tinggi. Akan tetapi perlu dilakukan penelitian pengaruh pemadatan Marshall berdiameter 6 inci.

Campuran Marshall kovensional 2x75 tumbukan dapat mendekati kondisi membal (kepadatan maksimum) tanpa harus menambah jumlah tumbukan jika menggunakan kadar aspal yang lebih tinggi.

\section{Daftar Pustaka}

AASHTO (2008): Standard Spesifications for Transportation Materials and Methods and Testing, Washington, USA.

Asphalt Institute. (1995) : Mix Design Methods for Asphalt Concrete and Other HotMix Types. MS-2. Kentucky. USA.

Bina Marga (1999): Pedoman Perencanaan Campuran Beraspal Panas dengan Pendekatan Kepadatan Mutlak, No.025/T/BM/1999, Indonesia

Bina Marga (2010): Spesifikasi Umum Untuk Pekerjaan Konstruksi Jalan dan Jembatan, Revisi 3, Indonesia.

British Standard BS 598-104 (2005): Sampling and Examination of Bituminous Mixtures for Roads and Other Paved Areas, UK.

Dachlan, A.T. (1997): Improved Indonesian Procedure for Asphalt Design, Journal of the Eastern Asia Society for Transportation Studies, Vol. 2, Autumn.

Kurnia, R. (2014) : Kinerja Campuran Beraspal Lapis Pengikat Menggunakan Aspal Pen 40/50 Dengan Variasi Gradasi Bina Marga dan Asphalt Institute (Bagian Dari Studi Perpetual Pavement), Thesis, Institut Teknologi Bandung, Indonesia.

Shuler, T.S., Huber, G.A. (1992): Refusal Density of Asphalt Concrete, ASTM STP 1147, Philadelphia, USA.
Sukirman, S. (2003): Beton Campuran Aspal Panas, Penerbit Nova, Bandung, Indonesia.

PUERI PERBANDINGAN KEPADATAN MARSHALL DAN KEPADATAN MUTLAK (PRD) PADA CAMPURAN BERASPAL 